\title{
Stephanie Kelton, The Deficit Myth: Modern Monetary Theory and the Birth of the People's Economy
}

\section{PublicAffairs, New York. ISBN-13: 978-1541736184}

\author{
Terence C. Burnham ${ }^{1}$ \\ Published online: 29 September 2020 \\ (c) Springer Science+Business Media, LLC, part of Springer Nature 2020
}

\section{Modern Monetary Theory (MMT)}

The Deficit Myth is written by Professor Stephanie Kelton, one of the leading proponents of Modern Monetary Theory (MMT). This review summarizes the major tenets of MMT as articulated by Professor Kelton, places MMT into a broad bioeconomic framework, and then concludes with some statements of the possible validity of MMT.

What is MMT? Professor Kelton introduces MMT by writing, "there are no constraints on the federal budget." (p. 2). The first 'M' in MMT is for modern. Before modern theory, economists evaluated government spending using old (incorrect) monetary theory. Consequently, governments have tended to spend too little causing unnecessary, missed opportunities to improve society.

In June 2020, for example, the US government spent almost a trillion dollars more than it received. Such statistics are best measured against the size of the economy. By this "percent of GDP" metric, the US Federal deficit in the single month of June 2020, exceeded annual deficits in all but a few years, and even exceeded the deficit in some entire decades.

Should we worry about government overspending such as these recent, record deficits? Critics of government deficits say, "we are burdening our children and grandchildren" or "The piper is going to have to be paid."

The logic of these 'old monetary theory' fears is that debts need to be repaid. Live like the grasshopper today by overspending, and die like the grasshopper in the future because winter is coming.

Stark views about winter coming are wrong, according to MMT, because the US government can print, or electronically create, any amount of money.

The essence of MMT is, “The federal government shouldn't try to manage its budget 'like a family sitting around the dinner table.' We don't need to tighten our belts with

Terence C. Burnham

burnham@chapman.edu

1 Chapman University, Orange, CA, USA 
shared sacrifice and fiscal restraint ... citizens should never be forced to suffer harsh austerity on the grounds that the government lacks the ability to pay for health care or pay benefits to retirees or the disabled." (p. 180).

MMT argues that misguided debt fears produce real economic pain. For example, President Obama suffered from 'the deficit myth.' In 2009, President Obama took office in the midst of financial crisis.

At the time, the Democrat party had control of both the House and the Senate, so President Obama had wide latitude regarding the size of the increased spending response to the crisis. The Obama administration considered spending between $\$ 787$ billion to up to $\$ 1.8$ trillion.

What happened? "In the end, Obama lost his nerve." (p. 6). According to Professor Kelton, President Obama should have spent more. "By not getting the policy response right, we set the stage for a slow and weak recovery that harmed our communities and translated into trillions of dollars in foregone prosperity for our economy." (p. 7).

President Obama hurt the people of the US because he spent too little. Historically, many other politicians have made similar mistakes by spending too little. "The federal government has historically almost always kept its deficit too small.” (p. 43).

Professor Kelton argues that President Obama could have spent much more and paid for the expenditures by creating more dollars. "The dollar is no longer tied to gold. The US issues a freely floating fiat currency so it doesn't need to tax or borrow before it can spend." (p. 98).

MMT states that there is no limit to the ability of the US government to fund expenditures by creating money. "If we wanted to, we could pay off the debt immediately with a simple keystroke." (pp. 10-11). "The entire national debt could be paid off tomorrow and none of us would have to chip in a dime." (p. 90).

The subtitle of the book includes "the Birth of the People's Economy". To achieve the People's Economy, we do not need hard choices, technological advances, or arms treaties; we just need to print more money.

"A just and more prosperous world-one that combines ecological sustainability with full employment, human well-being, a lower degree of inequality, and excellent public services that meet the needs of all—is within reach." (p. 260).

In summary, The Deficit Myth states that the US Government can create unlimited amounts of money, therefore debt and deficits do not matter. MMT is new, and before its creation by Professor Kelton and others, politicians and the public were negatively constrained by the old-fashioned view that government bills need to be repaid.

Once Modern Monetary Theory slays The Deficit Myth, the US will print enough money to achieve a better and more just society.

\section{Bioeconomics, money and MMT}

Before the invention of agriculture, roughly 12,000 years ago, the global human population was estimated at 6 million (Weiss 1984). In 2020, we approach a human population of 8 billion, more than a 1,000 fold increase.

What is the cause of the massive increase in human population? The answer, in part, is money. 
The overwhelming success of humans (now to the point of excess) lies in a series of cultural and technological advances. Money is an important innovation fueling economic and population growth.

The first forms of money were commodities such as rice and cheese. Such 'commodity currencies' have intrinsic value, and serve as a direct form of stored wealth. Metal coins appear about the fifth century BCE. Unlike commodity currencies, coins cannot be eaten, but they are more portable and are not subject to high storage costs or decay.

In recent decades, 'fiat' currencies have come to dominate. Fiat currencies have no intrinsic value, and are not backed by gold or any other assets. Goldie Hawn's character in Private Benjamin bemoans the death of her rich husband by saying, "it's not the money I'll miss, it's the things." Spoken like a true economist.

Can creating more of a fiat currency-e.g., printing more US dollars-make us richer? Yes, creating money can alter real wealth, but only by impacting the production and distribution of items with intrinsic value - the "things" missed by newly widowed, and soon to become Private, Benjamin.

It is easy to believe that human success derives exclusively from technology in the form of farming, motors, computers, and robots. However, cultural features such as contracts, courts, laws, police, and money, nurture the conditions for innovation.

Would Elon Musk work as hard to produce electric cars if someone could seize his wealth? Probably not. So institutional development is central to technological advancement.

Money lubricates mutually advantageous exchange. Without money, economic transactions require either a contemporaneous exchange (barter) or the creation of debt.

Barter is inefficient because wants are often not simultaneous in time or geography. Similarly, promises to repay are often broken or renegotiated. Fears of default prevent some valuable transactions from occurring.

With money, each party leaves a transaction immediately better off. Furthermore, no one needs to haul away a massive wheel of cheese, or worry about future repayment.

Money, and other cultural innovations, foster cooperation where different individuals work toward joint goals. This ability to cooperate in smaller and larger groups is central to biological success. So much so that the earth is dominated by the multicellular animals that have best mitigated the problem of cooperation.

If we use biomass as a definition of biological success, there are two types of multicellular animals that dominate the terrestrial part of the planet. These two are eusocial insects (mainly ants and termites) and humans, along with our domesticated livestock. Human biomass today is more than 10 times the mass of all wild mammals combined (Bar-On et al. 2018).

Cooperation is thus central to evolutionary success. Eusocial insects cooperate largely through kin selection (Hamilton 1964). In kin selection, organisms are 'paid' through their shared genes. Thus, natural selection favors ant cooperation even if one ant benefits at the expense of one of her sisters. There is no need for repayment within an ant colony.

As with ants, kin selection is centrally important to human cooperation. However, where humans excel, relative to other animals, is the ability to work with individuals 
who are not close relatives. Human cooperation with non-kin is primarily modulated by reciprocal altruism (Trivers 1971).

Reciprocal altruism explains the human ability to monitor and adjust the costs and benefits of cooperation. The upside of cooperation is the ability to jointly have more wealth. However, cooperators must guard against cheaters who attempt to capture more than half of the gains from cooperation.

Psychological mechanisms to modulate reciprocal altruism are part of a universal human nature. The ability to cooperate with non-kin has been central to human success since the Pleistocene.

Money is a cultural innovation that dramatically improves the ability of humans to cooperate with non-relatives. For example, a farmer can buy seeds and plant them in the spring, then harvest and sell the crop in the fall. The ability to easily store and transfer value using money increases overall societal wealth because it facilitates increased economic activity.

Money has played an important role in the incredible success of humans. Cultural innovations, including money, help humans cooperate with non-relatives in a manner that is qualitatively different from all other organisms.

Thus, when we analyze MMT, we analyze it through the effect on real goods and services. Printing an extra trillion of a fiat currency does not directly increase or decrease real wealth. Rather, the impact of monetary policy is measured by the change in the total amount of goods and services, and the division of those real assets among different people.

\section{Is MMT correct?}

In The Deficit Myth, Professor Kelton argues that bigger government deficits combined with money creation will create real wealth. MMT will lubricate the economic transactions and foster better and more efficient human cooperation.

Is MMT correct? Yes, no, or maybe?

Let us analyze MMT using one of the specific policy prescriptions from The Deficit Myth. Professor Kelton advocates spending more money on health care. "We'll need to build more hospitals and community health centers, invest more heavily in medical research." (p. 207).

Furthermore, these investments require utilization of resources. "Financing isn't a constraint; real resources are. Closing the health-care deficit will require more primary care doctors, nurses, dentists, surgeons, medical equipment, hospital beds, and so on." (p. 207).

Suppose the US decides to spend an extra trillion dollars a year on health care as Professor Kelton suggests. Does the size of the economy grow by more than one trillion dollars, by exactly one trillion dollars, by less than one trillion dollars, not grow at all, or shrink? 
Here are three possible answers.

(A) The economy grows by more than $\$ 1$ trillion.

The government prints and spends $\$ 1$ trillion. The recipients spend the $\$ 1$ trillion on new cars, vacations, education and health care. The people who sell the cars and vacations, then spend the money again. \$1 trillion is magnified by the 'Keynesian multiplier' to become more than $\$ 1$ trillion.

(B) The economy grows by less than $\$ 1$ trillion.

The government prints and spends $\$ 1$ trillion. Most of the new economic activity is taken from other areas. For example, a budding scientists leaves her laboratory position to become a primary care physician for a community that previously had no doctor. There are gains and losses from the additional spending; the gains outweigh the losses so the economy grows, but by less than $\$ 1$ trillion.

(C) The economy shrinks.

The government prints and spends $\$ 1$ trillion. The government is worse at making economic decisions so every $\$ 1$ spent by the government decreases economic activity by more than $\$ 1$. Thus, the more the government spends, the smaller the economy becomes. Visit Venezuela or Weimer Germany to see this in action.

Do you vote for A, B, or C? Does government spending in the US and other rich countries grow the economy? If so, by a lot or a little?

Economists have very strong opinions with most arguing that MMT is "magical thinking". It strikes most economists as preposterous that running the printing presses, both literal and figurative, is the way to make a country richer. If you bring up MMT in academic circles, you can count the seconds until someone reminds us of the hyperinflation of Weimar Germany or modern day Zimbabwe.

Now is when you expect me to reveal the answer. Is it A, B, or C? Does government spending make the society a lot richer, a little richer, or poorer?

The answer is that we do not know if MMT is correct. There is no consensus within economics on the impact of additional government deficit spending paid for by the creation of money.

Central bankers state that printing money 'supports' the economy. Critics, such as Stanford Professor John Taylor, disagree testifying to congress that, "these (Federal Reserve) policies have been a drag on the recovery" (Taylor 2013). What is striking about this divergence is that economists cannot even agree on whether more spending increases or decreases the size of the economy.

Consider what other fields would look like if they suffered similar gaps in consensus. For example, Aristotle argued that heavy objects fall faster than lighter objects. Many years later Galileo disagreed with Aristotle's theory. In his famous Leaning Tower of Pisa experiment, Galileo found support for his theory that the falling speed is the same for different masses. 
When the objects are dropped in a vacuum, physicists now know that Galileo was right and Aristotle was wrong on this topic. Even during the period of dispute, however, both scientific theories agreed on the direction that an object would move. If natural scientists disagreed to the same extent as economists, some physicists would argue that an untethered bowling ball might float off a tower into the clouds.

The secret shame of economics is that very little work focuses on the important issues of fiscal and monetary policy. Perhaps because these issues are so challenging, most economist have given up. Instead of working on fiscal and monetary policy, the field focuses on esoteric minutia.

Without validated theories of the impact of MMT, we can make only weak inferences based on historical outcomes. It appears nearly certain that it is possible to print and spend so much that the real economy grinds to a halt. The relevant question is how much is too much and where are we today in this range of effects?

We can look to current policies for clues.

Central banks around the world are, in fact, following MMT today, and have been for some years. Consider that it took almost a century for the Federal Reserve to create the first trillion dollars. Then, the Fed e-printed three trillion dollars in just a few years around the time of the 2007-2009 financial crisis. Most recently, in a matter of weeks, during the early stages of Covid-19, the Fed created another three trillion. Meanwhile the US Federal Government annual deficit rose to approximately $\$ 3$ trillion.

We are living in the MMT experiment proposed by Professor Kelton. The government spends without concern for the deficit and the Fed prints money to cover the expenditure.

What has been the impact of MMT? There are obvious beneficiaries from money creation to fund government expenditures, and no large-scale crash yet caused by ultra-loose monetary policy.

The most frequently cited cost of MMT, by both critics and by Professor Kelton, is inflation. Printing money, it is feared, will cause prices to rise and thereby harm people who do not receive part of the newly created money. As measured by standard price indices, such as the GDP deflator, there is no current sign of high US inflation. Of course, MMT-induced consumer price inflation could arise in the future. Beyond inflation, there are other less-cited risks from MMT. For example, the real interest rate-the inflation-adjusted rate-could increase thereby hurting borrowers.

Finally, we may already be suffering from MMT. Professor Kelton argues that the economy would have been more robust if President Obama had spent more money. Because no one knows the impact of printing and spending, however, it is possible that the economy may have been stronger if President Obama had spent less. Similarly, we might have a better economy today if the Fed had not printed three trillion dollars so far in 2020.

Japan has followed MMT for longer than the US. The Japanese stock market is 50\% below its level in 1989. The population of Japan is aging and shrinking. Decades of MMT in Japan correlate with stagnation and decline. Did MMT cause these Japanese problems? Again, no one knows, but still we wonder.

In conclusion, what can we say about MMT? Money creates wealth only via its impact on real goods and services. When too much money is created, it decreases overall wealth by inhibiting economic cooperation. Economic theory is silent on whether 
the world has created the Goldilocks' scenario of just the right amount of money, or too little or too much.

Recently, the US Federal Reserve and other central banks have implemented MMT by printing money at gargantuan scale to pay for massive government expenditures. There is no compelling evidence that this experiment in MMT has severely impeded economic activity.

MMT is probably going to end in financial disaster. That being said, all the naysayers (including me) predicted collapse sooner. So, for now, MMT rules the world.

\section{References}

Bar-On, Y. M., Phillips, R., \& Milo, R. (2018). The biomass distribution on Earth. Proceedings of the National Academy of Sciences of the United States of America, 115(25), 6506-6511.

Hamilton, W. D. (1964). The genetic theory of social behavior. I and II. Journal of Theoretical Biology, 7, $1-52$.

Taylor, J. B. (2013). A Steadier course for monetary policy. Economics Working Paper 13107.

Trivers, R. L. (1971). The evolution of reciprocal altruism. The Quarterly Review of Biology, 46(1), 35-57.

Weiss, K. M. (1984). On the number of members of the genus Homo who have ever lived, and some evolutionary implications. Human Biology, 56(4), 637-649.

Publisher's Note Springer Nature remains neutral with regard to jurisdictional claims in published maps and institutional affiliations. 